\title{
Modeling Post-Fire Tree Mortality Using a Logistic Regression Method within a Forest Landscape Model
}

\author{
Jacob S. Fraser ${ }^{1, *}$, Wen J. Wang ${ }^{1}$, Hong S. He ${ }^{1}$ and Frank R. Thompson III ${ }^{2}$ \\ 1 School of Natural Resources, University of Missouri, 203 ABNR Bldg, Columbia, MO 65211, USA; \\ wangwenj@missouri.edu (W.J.W.); heh@missouri.edu (H.S.H.) \\ 2 USDA Forest Service, Northern Research Station, 202 ABNR Bldg., Columbia, MO 65211, USA; \\ frthompson@fs.fed.us \\ * Correspondence: fraserjs@missouri.edu; Tel.: +1-573-882-7717
}

Received: 6 December 2018; Accepted: 27 December 2018; Published: 3 January 2019

\begin{abstract}
Fire is a multi-scale process that is an important component in determining ecosystem age structures and successional trajectories across forested landscapes. In order to address questions regarding fire effects over large spatial scales and long temporal scales researchers often employ forest landscape models which can model fire as a spatially explicit disturbance. Within forest landscape models site-level fire effects are often simplified to the species, functional type, or cohort level due to time or computational resource limitations. In this study we used a subset of publicly available U.S. Forest Service forest inventory data (FIA) to estimate short-term fire effects on tree densities across multiple stem diameter classes in two ecological sections in the central and southern United States. We found that FIA plots where low-intensity fires occurred within the preceding five years in the Ozark Highlands ecological section had significantly reduced stem densities in the two smallest diameter classes and in the Gulf Coastal Plains and Flatwoods fire reduced stem densities in the three smallest diameter classes. Using an independent subset of FIA plots we then parameterized and calibrated a forest landscape model to simulate site-level fire effects using a logistic regression based method and compare the results to previous methods of modeling fire effects. When representative landscapes from both study areas were simulated under a low-intensity fire regime using a forest landscape model the logistic regression probability method of modeling fire effects produced a similar reduction in stem densities while the previous age-cohort method overestimated density reductions across diameter classes. A more realistic representation of fire effects, particularly in low intensity fire regimes, increases the utility of forest landscape models as tools for planning and management.
\end{abstract}

Keywords: forest landscape modeling; fire effect modeling; LANDIS PRO

\section{Introduction}

Fire is an important driver that shapes forested landscapes due to the interactions between the frequency, intensity, and absence of fire with forest succession which can determine species composition and stand structure at varying spatial scales [1-3]. The alteration of fire regimes across the eastern United States by humans has resulted in drastic reductions in the area burned over the past century which has likely led to changes in forest species and structure compositions [4,5]. There is evidence that in the future climate change could have a direct effect of increasing fire potential across the region [6]. Recently, the use of fire as a management tool has increased as managers look for new tactics to increase forest resilience, restore desirable historical conditions, or control invasive species [6-11].

Researchers often employ models to study the effects of fire as a management tool or stochastic natural process under novel conditions, long temporal scales, or large spatial scales [12-15]. The method of modeling fire effects can determine the effective spatial and temporal scope of the 
results [16]. Models which simulate fire effects directly on individuals, often called first-order fire effects [16,17], use mechanistic processes or empirically-based probabilities to determine injury or death caused directly by fire. Due to their complexity, first-order fire effects models often operate at short temporal time scales (daily or sub-daily) or small spatial scales (individual tree or stand) which can limit the applicability of their predictions in long-term management or strategic planning contexts [18]. Another class of model represents the aggregated effects of fire on individuals as changes in vegetation types or land cover classes using either mechanistic or rule based state-transition methods. These models, referred to as second-order fire effect models, can simulate larger landscapes over longer time periods, although usually at the expense of tracking site-level details of forest composition [19]. Over the course of several decades many models have been developed that use one, or both methods of simulating fire effects in order to provide information to answer a variety of research and management related questions.

One such example are forest landscape models (FLMs) which have been developed specifically to combine the interactions between spatial processes of disturbance and dispersal with site-level community dynamics. Since the spatial component of disturbances is one of the main focuses of FLMs, it is unsurprising that model developers have focused considerable effort on the ignition and spread components of fire disturbance $[2,12,20,21]$. The method for modeling fire effects within FLMs is often implemented using a rule-based community transition method where specific age cohorts, species, or some combination of both are removed from a site where fire occurs [21]. Most FLMs have a main component to simulate forest succession which interacts with separate disturbance modules by means of a biological or ecological model currency, which in the case of fire effects has typically been the presence or absence of specific species or age cohorts [22,23]. Fire effects are represented by a specific set of these cohorts being removed from a site following a set of user-defined rules. A few, more complex and computationally intensive, FLMs model fire mortality at the individual level using empirical logistic regression probability equations $[19,24,25]$. By combining the feedback from the fire effect modules with forest succession, species dispersal, and other disturbance mechanisms researchers can use forest landscape models to examine the role that fire plays across broad spatial and temporal scales that are not often feasible in direct field studies.

One area that presents opportunities for improving the utility of model predictions for management and planning decisions is the ability of FLMs to interface with common forest management and ecological monitoring sampling practices. Forest inventories typically record the species and diameter at breast height $(1.5 \mathrm{~m})$ above ground for every tree on a plot which can then be scaled to per hectare estimates of basal area and densities or aboveground biomass weights using allometric equations [26]. Researchers have used forest inventory data in order to construct initial forest community conditions as a starting point for FLMs [27,28]. These initial community definitions are typically structured as quantitative information describing cohorts of similar individuals which are grouped by species, functional type, developmental stage, size, age, or some combination of multiple factors. The cohorts represented in early models were typically the presence or absence of age classes by species [29], or forest type on each site [30]. As computational resources improved FLMs were able to track more detailed quantitative information about cohorts within the model such as biomass [31], number of individuals [28], or specific individuals [24] which allowed a more direct comparison with forest inventory data for the purposes of model initialization, calibration, and validation [32]. This also allows for the possibility of model predictions to be directly compared with studies of forest fire ecology [10,33], silvicultural management [34,35], and wildlife population modeling [36,37].

We present an approach to modeling first-order fire effects using a logistic regression probability method within a FLM, LANDIS PRO. With development of LANDIS PRO version 7.0 the presence/absence age cohort structure of tracking species over the landscape was replaced with one that could directly track number of individual stems within each age cohort [28]. This allows the model to simulate partial effects of disturbance processes at the site-level and more realistically represent some stand dynamics [38,39] while still operating at fine spatial resolutions $(30-270 \mathrm{~m})$ 
over large landscapes. We demonstrate how widely available forest inventory data is utilized to initialize forest communities within the model and calibrate the fire effects model as well as validate model predictions. The objectives of this study are: (1) Compare stem densities by size class on forest inventory plots in the eastern United States to test the hypothesis that small diameter stem densities are reduced on plots where low-intensity fire has occurred within the previous five years; (2) Test if a logistic regression based fire effects model and a rule-based model are effective predicting stem densities following a low-intensity fire within a forest landscape model.

\section{Materials and Methods}

\subsection{Study Area}

For this study we chose two different regions that represent different forest types and fire regimes (Figure 1). The Ozark Highlands ecological section is primarily located in southern Missouri and northern Arkansas. The forest cover types are largely composed of oak-hickory and oak-pine forests [40]. Quercus alba L. (white oak) accounts for $24 \%$ of forest biomass in the region, while the next nine most abundant species account for an additional $50 \%$ of forest biomass (Table 1 ).

Table 1. The top ten most abundant species in the Ozark Highlands ecological section by percentage of total aboveground biomass as reported by the U.S. Forest Service Forest Inventory and Analysis estimate from plots sampled between the years 2011-2015.

\begin{tabular}{ccc}
\hline Species Latin Name & Species Common Name & Biomass Percentage \\
\hline Quercus alba L. & white oak & 22.5 \\
Quercus velutina Lam. & black oak & 15.0 \\
Quercus stellate Wangenh. & post oak & 10.5 \\
Quercus rubra L. & northern red oak & 5.1 \\
Pinus echinata Mill. & shortleaf pine & 4.2 \\
Quercus coccinea Münchh. & scarlet oak & 4.1 \\
Juniperus virginiana L. & eastern redcedar & 2.9 \\
Carya tomentosa Lam. & mockernut hickory & 2.6 \\
Carya texana Buckley & black hickory & 2.5 \\
Acer saccharum Marshall & sugar maple & 2.5 \\
\hline
\end{tabular}

The Gulf Coastal Plains and Flatwoods section is located mainly in the southern portions of Mississippi, Alabama, and Georgia while also covering parts of eastern Louisiana and northern Florida. The region is dominated by southern pine forest types with mixed hardwoods. Pinus taeda L. (loblolly pine) accounts for nearly $40 \%$ of forest biomass in the region while other common species include Quercus nigra L. (water oak), Liquidambar styraciflua L. (sweetgum), Pinus elliottii Engelm. (slash pine), Quercus laurifolia Michx. (laurel oak), Liriodendron tulipifera L. (yellow-poplar), Quercus alba L. (white oak), Pinus palustris Mill. (longleaf pine), and Pinus echinata Mill. (shortleaf pine) (Table 2).

Table 2. The top ten most abundant species in the Gulf Coastal Plains ecological section by percentage of total aboveground biomass as reported by the U.S. Forest Service Forest Inventory and Analysis estimate from plots sampled between the years 2011-2015.

\begin{tabular}{ccc}
\hline Species Latin Name & Species Common Name & Biomass Percentage \\
\hline Pinus taeda L. & loblolly pine & 38.0 \\
Quercus nigra L. & water oak & 10.9 \\
Liquidambar styraciflua L. & sweetgum & 7.1 \\
Pinus elliottii Engelm. & slash pine & 4.6 \\
Quercus laurifolia Michx. & laurel oak & 4.0 \\
Liriodendron tulipifera L. & yellow-poplar & 3.2 \\
Quercus alba L. & white oak & 2.3 \\
Pinus palustris Mill. & longleaf pine & 2.3 \\
Pinus echinata Mill. & shortleaf pine & 2.2 \\
Nyssa sylvatica Marshall & blackgum & 2.1 \\
\hline
\end{tabular}




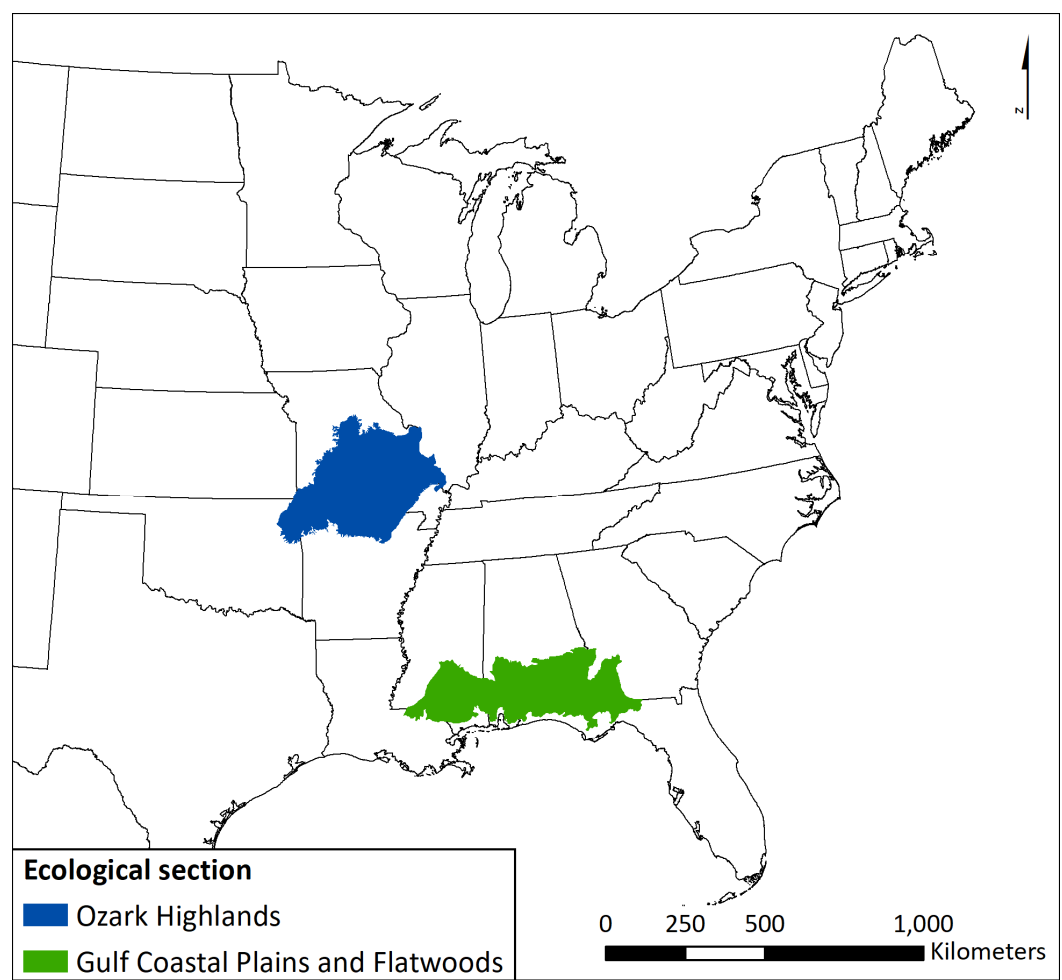

Figure 1. Two ecological sections containing forest inventory plots used for analysis, model parameterization, and validation.

\subsection{Model Parameterization}

LANDIS PRO is a grid-cell based spatially explicit forest landscape model that can simulate large landscapes over long temporal scales at a user-specified spatial resolution [28]. By tracking stem density within age classes for individual species occupying each cell the model can simulate demography, stand dynamics, and disturbance. LANDIS PRO requires input parameters detailing species attributes, land type attributes, forest composition, and disturbance characteristics.

Biological attributes for 29 species were collected from previous studies and literature [38,41-43]. Within the model each species is divided into age cohorts based on the simulation time-step and species longevity. For example, if a species has a longevity within the model of 100 years and the simulation time-step is set to two years the species would have 50 individual age cohorts. For this experiment we chose a two year time-step. Stem diameter for each species within the model is determined by age. We calibrated these age-diameter relationships using U.S. Forest Service Inventory and Analysis (FIA) plot site-index information from within the study areas recorded from 1995-2017 [38,44,45]. At the beginning of simulation in LANDIS PRO each pixel was assigned an initial forest community based on a single FIA plot. FIA records the species and diameter of each individual with a DBH greater than or equal to $2.54 \mathrm{~cm}$, allowing the inventory data to be directly transferred to the LANDIS PRO age/diameter cohort structure. Since this study focused on modeling site-level fire effects, the components of LANDIS PRO that simulate seed dispersal and establishment were deactivated and the land types of each pixel were assumed to be homogenous.

For this study we chose to model post-fire mortality using an equation based on studies using logistic regression to predict fire mortality using tree diameter at breast height (DBH) and height of charring on the stem [46-48]. A review of post-fire mortality logistic regression models western North America found that DBH was the most frequent significant variable among the models reviewed [48]. In a study that sampled over 2100 trees in oak-hickory forests DBH and height of bole scorching were the most important variables in predicting post-fire mortality of trees smaller than 16 inches DBH [49]. 
In a study of eastern mixed oak forests DBH and height of bole scorching were effective explanatory variables for predicting the probability of top-killing following fire [46].

The equation used in LANDIS PRO 7.0 to calculate probability of mortality following fire is as follows:

$$
P(m)=\left(1+e^{-\left(\beta_{0}+\beta_{1} X_{1}+\beta_{2} X_{2}\right)}\right)^{-1}
$$

$\beta_{i}=$ model coefficients

$X_{1}=$ tree diameter $(\mathrm{cm})$ at breast height,

$X_{2}=$ height of bark charring $(\mathrm{m})$.

The user provides five sets of model coefficients that correspond to the five fire tolerance classes for tree species. The $X_{2}$ parameter is used by the LANDIS PRO fire module analogously for fire severity. The user can set five values for $X_{2}$ that correspond to the five fire severity levels to produce a range of mortality probabilities for all combinations of species fire tolerances and fire severities.

We generated five sets of model coefficients for each study area that corresponded to the five fire tolerance classes that are part of species parameters within LANDIS PRO. The values for these parameters were estimated from previous studies in the two regions [10,46,50-52] and further calibrated using FIA data from plots sampled between the years 2006 and 2010 from each study area. The model coefficients for each fire tolerance class were adjusted from initial values so that post-fire densities by diameter class more closely followed those found in the FIA calibration dataset. The rule-based fire mortality model has no parameters that can be calibrated without altering code within the model and follows the rules presented in He \& Mladenoff, 1999 [12]. The fire tolerance of a species determines what percentage of cohorts are removed following a fire of a given intensity.

\subsection{Experimental Design}

For each of the ecological sections a randomly generated landscape was modeled in LANDIS PRO with 100 replications to ensure a heterogeneous application of fire on the landscape. Each replication was a 30 row and 30 column map composed of randomly selected pixels from the initial community map within the ecological section and regenerated for each replication. Initial communities were based on FIA plots sampled between the years 2011 and 2015. Fire is more frequent and on average of a higher severity in the Gulf Coastal Plains than in The Ozark Highlands, although both study area generally only experience low-intensity ground fires [53]. We used the LANDIS PRO fire module to apply fire to random pixels at a rate of 3.5\% of the landscape in the Ozark Highlands and $9.5 \%$ of the landscape in the Gulf Coastal Plains to match the approximated ratio of burned to unburned plots found in the FIA data. The fires simulated in the Ozark Highlands section were parameterized to be low-intensity surface fires of severity one, while the fires simulated in the Gulf Coastal Plains section were either severity one or two [53]. The LANDIS PRO fire module was modified to simulate both the original rule-based fire mortality and the logistic regression probability fire model and output stem densities by diameter classes for each method. The diameter classes are $\leq 5 \mathrm{~cm}, 5-10 \mathrm{~cm}, 10-15 \mathrm{~cm}$, $15-20 \mathrm{~cm}, 20-25 \mathrm{~cm}, 25-30 \mathrm{~cm}, 30-35 \mathrm{~cm}$, and $>35 \mathrm{~cm}$. All parameters controlling fire intensity and proportion of the landscape burned were held constant for both fire mortality modeling methods. For each replication the landscape was partitioned in to unburned and burned cells and tree densities for the eight diameter classes was extracted from each pixel.

The USDA Forest Service Forest Inventory and Analysis (FIA) [44] was utilized to validate modeled mortality following fire. For each ecological section FIA plots that had a record of fire occurring within the previous five years were identified. Trees within the plots were classified in to one of the eight diameter classes to match results from the LANDIS PRO output. Each diameter class was then summarized using the trees per acre expansion factor to produce density estimates from each plot. 


\subsection{Data Analysis}

The pairwise Wilcoxon rank sum test was used to test for differences in stem density for each diameter category across the burned FIA plots, unburned FIA plots, unburned LANDIS PRO pixels, logistic regression probability fire mortality pixels, and rule-based fire mortality pixels. The non-parametric Wilcoxon test was chosen due to unequal sample sizes across groups and non-normal distributions. All comparisons of significance were made using an $\alpha$ of 0.05 .

\section{Results}

\subsection{Ozark Highlands Section}

The stem densities for the $\leq 5 \mathrm{~cm}$ and the $5-10 \mathrm{~cm}$ class were significantly lower in burned FIA plots compared to FIA plots that were unburned in the Ozark Highlands section (Figure 2). All other diameter classes had no significant difference between burned and unburned plots in the FIA data. The predictions of stem density in burned pixels made by LANDIS PRO using the logistic regression fire effects model had no significant difference from burned FIA plots in the two smallest diameter classes. For all other diameter classes LANDIS PRO had no significant difference in stem densities between pixels burned using the logistic regression fire effects model and unburned pixels. Simulated pixels burned using the rule-based fire effects model were significantly lower than unburned pixels across all diameter classes.

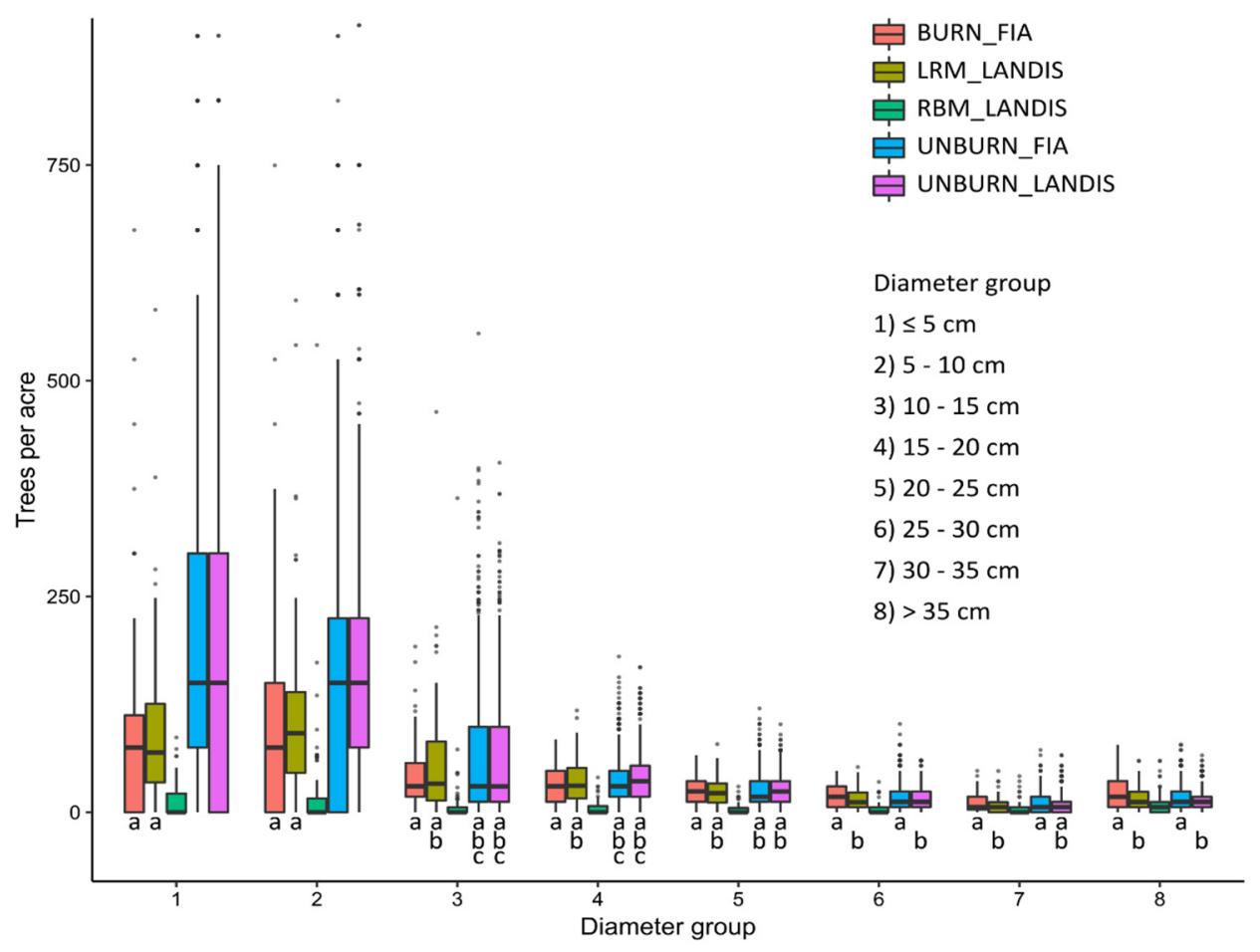

Figure 2. Boxplot showing stem densities within eight diameter groups from the Ozark Highlands study area. Estimates from U.S. Forest Service Forest Inventory and Analysis plots that experienced fire within the previous five years (BURN_FIA, $n=67$ ) are compared with plots with no recorded fire (UNBURN_FIA, $n=1972$ ), predictions made by LANDIS PRO using a logistic regression probability of fire mortality model (LRM_LANDIS), predictions made by LANDIS PRO using a rule-based fire mortality model (RBM_LANDIS), and predictions from LANDIS PRO with no fire (UNBURN_LANDIS). Letters below bars denote which density estimates did not differ significantly at an $\alpha$ of 0.05 using a pairwise comparison using the Wilcoxon rank sum test within each diameter group. 


\subsection{Gulf Coastal Plains Section}

Stem densities for the $\leq 5 \mathrm{~cm}$, the $5-10 \mathrm{~cm}$, and the $10-15 \mathrm{~cm}$ diameter classes were significantly lower on FIA plots with a recorded fire disturbance when compared to plots with no recorded fire. In the 15-20 cm, 20-25 cm, and 25-30 cm diameter classes there was no significant difference in stem densities among burned and unburned FIA plots (Figure 3). Within the $\leq 5 \mathrm{~cm}$ and $5-10 \mathrm{~cm}$ diameter classes predicted stem densities had significant decreases of approximately $50 \%$ using the logistic regression fire effects model while those using the rule-based model decreased by $90 \%$ and $50 \%$ respectively. There was no effect of fire for all larger diameter classes under the logistic regression fire effects model when compared to unburned pixels while the rule-based model predicted significantly lower stem density in most of the larger diameter classes.

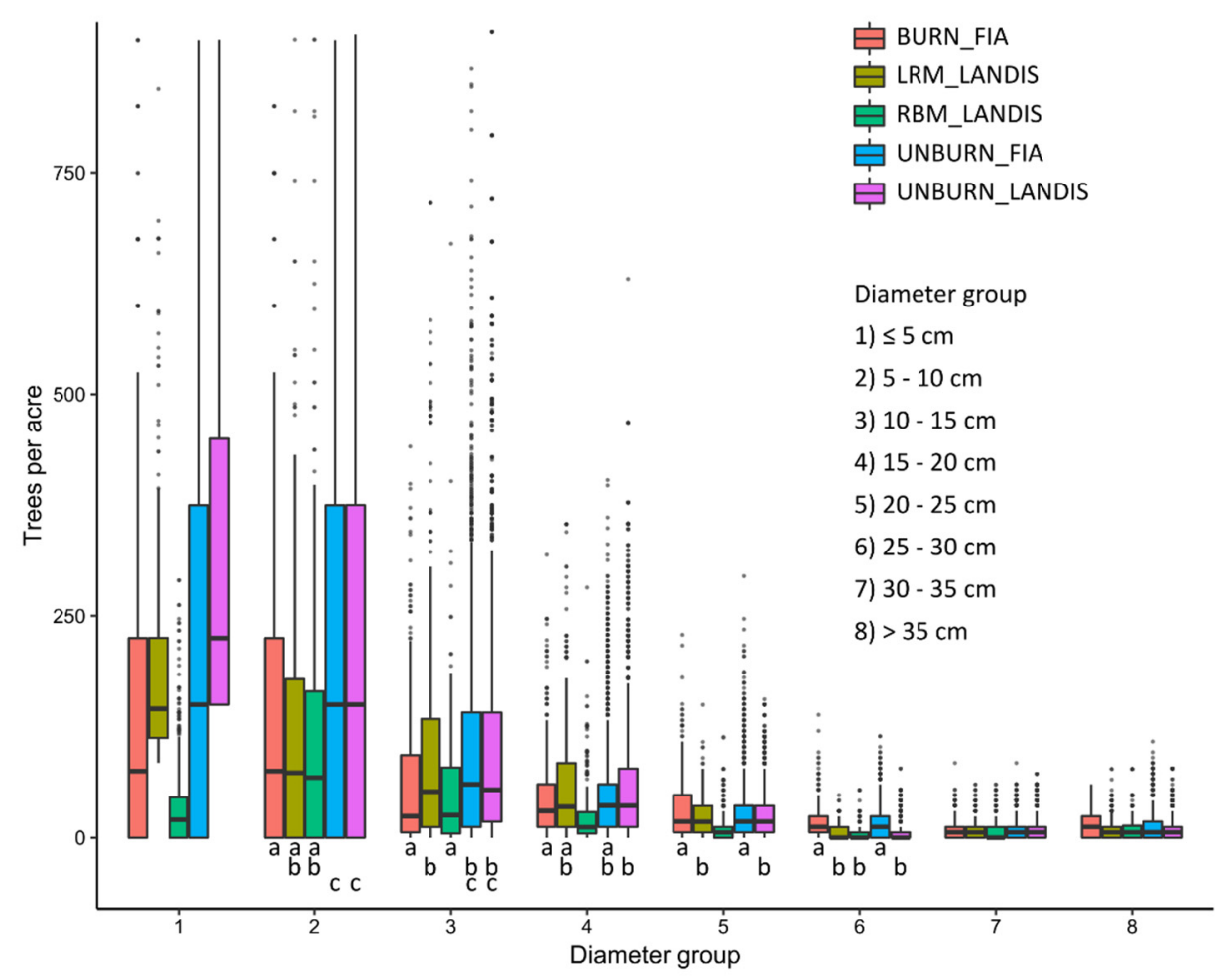

Figure 3. Boxplot showing stem densities within eight diameter groups from the Gulf Coastal Plains study area. Estimates from U.S. Forest Service Forest Inventory and Analysis plots that experienced fire within the previous five years (BURN_FIA, $n=423$ ) are compared with plots with no recorded fire (UNBURN_FIA, $n=4444$ ), predictions made by LANDIS PRO using a logistic regression probability of fire mortality model (LRM_LANDIS), predictions made by LANDIS PRO using a rule-based fire mortality model (RBM_LANDIS), and predictions from LANDIS PRO with no fire (UNBURN_LANDIS). Letters below bars denote which density estimates did not differ significantly at an $\alpha$ of 0.05 using a pairwise comparison using the Wilcoxon rank sum test within each diameter group.

\section{Discussion}

In an analysis of over 6000 forest inventory plot records we showed that plots with fire recorded within the previous five years had lower stem densities in diameter classes less than $10 \mathrm{~cm}$ in the Ozark Highlands and less than $15 \mathrm{~cm}$ in the Gulf Coastal Plains. These results are in agreement with a number of studies conducted within the study areas we examined or within systems with similar species composition and fire regimes. In a study conducted in mixed pine-hardwood forests of the southern Appalachians following a single fire of three different intensities there were few species in which stems less than $5 \mathrm{~cm}$ were completely removed [54], even under the highest observed fire intensity. In two studies conducted in southern Missouri Kinkead et al. [52] found that mortality 
rates for trees less than $11 \mathrm{~cm} \mathrm{DBH}$ ranged from $16 \%$ to $56 \%$ in oak-hickory forests following a single low-intensity fire while Dey and Hartman [55] found that no species had a complete removal of seedlings and saplings following a single burn. Brose et al. [51] found in a meta-analysis of studies from the eastern United States that mortality following a single fire in oak dominated forests mainly restricted to saplings less than $10 \mathrm{~cm} \mathrm{DBH}$, while larger size classes were less likely to be affected. Knapp et al. [10] found a decline in mid-story sapling (3-10 $\mathrm{cm} \mathrm{DBH)} \mathrm{density} \mathrm{following} \mathrm{periodic} \mathrm{burns}$ on plots located within the Ozark Highlands section. Hodgkins [56] found that southern pine forests in Alabama had significantly reduced understory stem densities of saplings $10 \mathrm{~cm}$ DBH or less following low-intensity fires. Waldrop and Lloyd [57] found that loblolly pine stands in South Carolina had significantly reduced stem densities following prescribed fire, with much of the mortality occurring in smaller diameter classes. Likewise, McNab [58] found that low-intensity fires reduced stem densities in loblolly pine stands in Georgia and that mortality was limited to trees $10 \mathrm{~cm} \mathrm{DBH}$ and smaller. Some studies have examined individual fire effects using FIA data in the western United States [59,60], although to our knowledge there have been no studies in the eastern United States.

In the field studies referenced above, one common finding is that there is rarely complete mortality in small diameter cohorts following low-intensity fires, even in fire intolerant species. In our results we found that predictions using a rule-based fire mortality model were significantly lower compared to the logistic regression probability model. This behavior is likely partially a result of how fire tolerance for a given species is represented in the model. In the Ozark Highlands half of the top 10 most abundant species in the region; black oak, scarlet oak, northern red oak, sugar maple, and mockernut hickory, have a fire tolerance rating in the model of two or less, meaning they are moderately to very intolerant of fire. Even the lowest intensity fire would kill 50 to $85 \%$ of cohorts in these species using the rule-based based mortality method. For example, black oak has a fire tolerance rating of two and a longevity of 150 years. In a low severity fire, using the rule-based fire mortality model, the smallest $50 \%$ of cohorts would be removed which corresponds to black oak individuals from $1-40 \mathrm{~cm} \mathrm{DBH}$. The Gulf Coastal Plains section is predominantly composed of loblolly pine which is parameterized in the model with a fire tolerance rating of four. This means that with a fire severity of two on the landscape, only loblolly pine individuals from 1-25 cm DBH would be removed using the rule-based fire effect model while under the diameter-based mortality probability trees at $2 \mathrm{~cm}$ have a $60 \%$ change of being killed which declines to $1 \%$ at $12 \mathrm{~cm}$. As the average fire tolerance of species increased across study areas, the difference between predictions from the two fire effects models was less severe.

By modeling fire effects using a calibrated logistic regression model we were able to predict post-fire stem densities for eight diameter classes that followed trends observed in inventory data while predictions using a rule-based fire effects model consistently under-predicted the residual stem densities following a fire. The residual small-diameter stems in stands that experience a low-intensity fire are an important component along with regeneration in determining the species composition and structure of the understory in the following years, particularly in plots that do not experience repeat fires $[1,51,55,56]$. Within LANDIS PRO the effects of wildfire and prescribed fire are modeled using the same method, with inputs from other modules determining the location and intensity of these fire events. The results presented here represent only the effects of fire on residual stem densities and do not include resprouting or seed regeneration which occur during a later process in LANDIS PRO. This is comparable to the observations of fire effects from FIA plots, which are resampled at five year intervals, and typically would not sample post-fire regeneration if the fire occurred within five years or less since there is a $2.54 \mathrm{~cm}$ DBH threshold for inclusion [60]. In addition, the observations of fire disturbance within FIA do not include information regarding the cause of fire which makes differentiating between wildfire and prescribed fire in the data difficult. The significant difference in size classes among FIA plots that were burned compared to those unburned highlights the utility of this database as a resource for parameterizing and calibrating forest landscape models and fire effect models. 
These results present an argument for a more empirically-based approach to modeling fire effects where probability of mortality for individuals within a cohort can be calibrated to a fire regime rather than completely removed. As computational resources have improved, FLM developers have been able to incorporate more mechanistic or empirical processes that typically had been limited to individual-based models. By modeling the site-level first-order fire effects which are then incorporated in forest succession, FLMs produce bottom-up predictions of second-order fire effects such as changes in species composition, forest structure, or carbon dynamics over time and space [61,62]. This differs from other regional scale spatial models such as dynamic global vegetation models (DGVMs) or state-transition models (STMs) which model second-order fire effects directly as represented by changes in vegetation type or reductions in carbon pools [63,64]. DGVMs and STMs have been used to explore the response of vegetation to climate at regional scales, however, the coarse spatial resolution, simplified demographic information, and difficulty representing management within these models limits their utility in strategic decision making processes [65]. A finer scale representation of first-order fire effects based on empirical or mechanistic processes can translate to improved modeling of second-order fire effects which are often more useful to managers or planners [16].

\section{Conclusions}

Here we have described an empirical modeling approach to fire mortality and showed how this method can realistically represent decreases in stem densities across diameter classes following low-intensity fires that are observed in field studies and inventory data. By examining forest inventory plot data we were able to support the hypothesis that small-diameter stem densities are lower on plots that have experienced low-intensity fire in the previous five years. We used forest inventory data to calibrate a logistic regression probability function to model fire effects within LANDIS PRO and compare predictions against a rule-based fire effects model. We found that the logistic regression fire effects model was able to reasonably predict reductions in stem densities following low-intensity fires while the rule-based fire effects model consistently overestimated mortality across size classes.

Author Contributions: Conceptualization, J.S.F.; Methodology, J.S.F. and W.J.W.; Data curation, J.S.F.; Formal analysis, J.S.F.; Investigation, J.S.F.; Writing-original draft, J.S.F.; Writing-review and editing, J.S.F., W.J.W., H.S.H. and F.R.T.

Funding: This research received no external funding.

Acknowledgments: We thank the two anonymous reviewers who provided comments and suggestions to improve this article.

Conflicts of Interest: The authors declare no conflict of interest.

\section{References}

1. Iverson, L.R.; Hutchinson, T.F.; Prasad, A.M.; Peters, M.P. Thinning, fire, and oak regeneration across a heterogeneous landscape in the eastern U.S.: 7-year results. For. Ecol. Manag. 2008, 255, 3035-3050. [CrossRef]

2. Sturtevant, B.R.; Scheller, R.M.; Miranda, B.R.; Shinneman, D.; Syphard, A. Simulating dynamic and mixed-severity fire regimes: A process-based fire extension for LANDIS-II. Ecol. Modell. 2009, 220, 3380-3393. [CrossRef]

3. Knapp, B.O.; Hullinger, M.A.; Kabrick, J.M. Effects of fire frequency on long-term development of an oak-hickory forest in Missouri, U.S.A. For. Ecol. Manag. 2017, 387, 19-29. [CrossRef]

4. Nowacki, G.J.; Abrams, M.D. The Demise of Fire and "Mesophication" of Forests in the Eastern United States. Bioscience 2008, 58, 123. [CrossRef]

5. Balch, J.K.; Bradley, B.A.; Abatzoglou, J.T.; Nagy, R.C.; Fusco, E.J.; Mahood, A.L. Human-started wildfires expand the fire niche across the United States. Proc. Natl. Acad. Sci. USA 2017, 114, 2946-2951. [CrossRef] [PubMed]

6. Mitchell, R.J.; Liu, Y.; O’Brien, J.J.; Elliott, K.J.; Starr, G.; Miniat, C.F.; Hiers, J.K. Future climate and fire interactions in the southeastern region of the United States. For. Ecol. Manag. 2014, 327, 316-326. [CrossRef] 
7. Brown, R.T.; Agee, J.K.; Franklin, J.F. Forest restoration and fire: Principles in the context of place. Conserv. Biol. 2004, 18, 903-912. [CrossRef]

8. Millar, C.I.; Stephenson, N.L.; Stephens, S.L. Climate change and forest of the future: Managing in the face of uncertanity. Ecol. Appl. 2007, 17, 2145-2151. [CrossRef] [PubMed]

9. Mitchell, R.J.; Hiers, J.K.; O'Brien, J.J.; Jack, S.B.; Engstrom, R.T. Silviculture that sustains: The nexus between silviculture, frequent prescribed fire, and conservation of biodiversity in longleaf pine forests of the southeastern United States. Can. J. For. Res. 2006, 36, 2724-2736. [CrossRef]

10. Knapp, B.O.; Stephan, K.; Hubbart, J.A. Structure and composition of an oak-hickory forest after over 60 years of repeated prescribed burning in Missouri, U.S.A. For. Ecol. Manag. 2015, 344, 95-109. [CrossRef]

11. Buma, B.; Wessman, C.A. Disturbance interactions can impact resilience mechanisms of forests. Ecosphere 2011, 2, 1-13. [CrossRef]

12. He, H.S.; Mladenoff, D.J. Spatially explicit and stochastic simulation of forest-landscape fire disturbance and succession. Ecology 1999, 80, 81-99. [CrossRef]

13. Jin, W.; He, H.S.; Shifley, S.R.; Wang, W.J.; Kabrick, J.M.; Davidson, B.K. How can prescribed burning and harvesting restore shortleaf pine-oak woodland at the landscape scale in central United States? Modeling joint effects of harvest and fire regimes. For. Ecol. Manag. 2018, 410, 201-210. [CrossRef]

14. Keane, R.E.; Ryan, K.C.; Running, S.W. Simulating effects of fire on northern Rocky Mountain landscapes with the ecological process model FIRE-BGC. Tree Physiol. 1996, 16, 319-331. [CrossRef] [PubMed]

15. Boulanger, Y.; Taylor, A.R.; Price, D.T.; Cyr, D.; Sainte-Marie, G. Stand-level drivers most important in determining boreal forest response to climate change. J. Ecol. 2017, 106, 977-990. [CrossRef]

16. Reinhardt, E.D.; Keane, R.E.; Brown, J.K. Modeling fire effects. Int. J. Wildl. Fire 2001, 10, 373-380. [CrossRef]

17. Reinhardt, E.D.; Dickinson, M.B. First-order fire effects models for land management: Overview and issues. Fire Ecol. 2010, 6, 131-150. [CrossRef]

18. Butler, B.W.; Dickinson, M.B. Tree injury and mortality in fires: Developing process-based models. Fire Ecol. 2010, 6, 55-79. [CrossRef]

19. Keane, R.E.; Cary, G.J.; Flannigan, M.D.; Parsons, R.A.; Davies, I.D.; King, K.J.; Li, C.; Bradstock, R.A.; Gill, M. Exploring the role of fire, succession, climate, and weather on landscape dynamics using comparative modeling. Ecol. Modell. 2013, 266, 172-186. [CrossRef]

20. Yang, J.; He, H.S.; Sturtevant, B.R.; Miranda, B.R.; Gustafson, E.J. Comparing effects of fire modeling methods on simulated fire patterns and succession: A case study in the Missouri Ozarks. Can. J. For. Res. 2008, 38, 1290-1302. [CrossRef]

21. Keane, R.E.; Cary, G.J.; Davies, I.D.; Flannigan, M.D.; Gardner, R.H.; Lavorel, S.; Lenihan, J.M.; Li, C.; Rupp, T.S. A classification of landscape fire succession models: Spatial simulations of fire and vegetation dynamics. Ecol. Modell. 2004, 179, 3-27. [CrossRef]

22. Scheller, R.M.; Domingo, J.B.; Sturtevant, B.R.; Williams, J.S.; Rudy, A.; Gustafson, E.J.; Mladenoff, D.J. Design, development, and application of LANDIS-II, a spatial landscape simulation model with flexible temporal and spatial resolution. Ecol. Modell. 2007, 201, 409-419. [CrossRef]

23. He, H.S.; Bu, R.; Yang, J.; Shifley, S.R.; Sturtevant, B.R.; Gustafson, E.J.; Mladenoff, D.J. LANDIS, a Spatially Explicit Model of Forest Landscape Disturbance, Management, and Succession-LANDIS 6.0 Pro Users Guide; University of Missouri: Columbia, MO, USA, 2009.

24. Seidl, R.; Rammer, W.; Scheller, R.M.; Spies, T.A. An individual-based process model to simulate landscape-scale forest ecosystem dynamics. Ecol. Modell. 2012, 231, 87-100. [CrossRef]

25. Schumacher, S.; Reineking, B.; Sibold, J.; Bugmann, H. Modeling the impact of climate and vegetation on fire regimes in mountain landscapes. Landsc. Ecol. 2006, 21, 539-554. [CrossRef]

26. Jenkins, J.C.; Birdsey, R.A. Validation Databases for Simulation Models: Aboveground Biomass and Net Primary Productivity (NPP) Estimation Using Eastwide FIA Data; U.S. Department of Agriculture, Forest Service, North Central Forest Experiment Station: St. Paul, MN, USA, 2000.

27. Duveneck, M.J.; Thompson, J.R.; Gustafson, E.J.; Liang, Y.; de Bruijn, A.M.G. Recovery dynamics and climate change effects to future New England forests. Landsc. Ecol. 2016, 32, 1385-1397. [CrossRef]

28. Wang, W.J.; He, H.S.; Spetich, M.A.; Shifley, S.R.; Thompson, F.R., III; Larsen, D.R.; Fraser, J.S.; Yang, J. A large-scale forest landscape model incorporating multi-scale processes and utilizing forest inventory data. Ecosphere 2013, 4, 1-22. [CrossRef] 
29. He, H.S.; Mladenoff, D.J.; Boeder, J. An object-oriented forest landscape model and its representation of tree species. Ecol. Modell. 1999, 119, 1-19. [CrossRef]

30. Chew, J.; Stalling, C.; Moeller, K. Integrating knowledge for simulating vegetation change at landscape scales. West. J. Appl. For. 2004, 19, 102-108.

31. Scheller, R.M.; Van Tuyl, S.; Clark, K.L.; Hom, J.; La Puma, I. Carbon sequestration in the New Jersey pine barrens under different scenarios of fire management. Ecosystems 2011, 14, 987-1004. [CrossRef]

32. Wang, W.J.; He, H.S.; Spetich, M.A.; Shifley, S.R.; Thompson, F.R.; Dijak, W.D.; Wang, Q. A framework for evaluating forest landscape model predictions using empirical data and knowledge. Environ. Model. Softw. 2014, 62, 230-239. [CrossRef]

33. Bottero, A.; D'Amato, A.W.; Palik, B.J.; Kern, C.C.; Bradford, J.B.; Scherer, S.S. Influence of repeated prescribed fire on tree growth and mortality in Pinus resinosa forests, northern Minnesota. For. Sci. 2017, 63, 94-100. [CrossRef]

34. Tuten, M.C.; Sánchez Meador, A.; Fulé, P.Z. Ecological restoration and fine-scale forest structure regulation in southwestern ponderosa pine forests. For. Ecol. Manag. 2015, 348, 57-67. [CrossRef]

35. Kabrick, J.M.; Clark, K.L.; D’Amato, A.W.; Dey, D.C.; Kenefic, L.S.; Kern, C.C.; Knapp, B.O.; MacLean, D.A.; Raymond, P.; Waskiewicz, J.D. Managing hardwood-softwood mixtures for future forests in eastern North America: Assessing suitability to projected climate change. J. For. 2017, 115, 190-201. [CrossRef]

36. Bonnot, T.W.; Thompson, F.R.; Millspaugh, J.J. Dynamic-landscape metapopulation models predict complex response of wildlife populations to climate and landscape change. Ecosphere 2017, 8, e1890. [CrossRef]

37. Shifley, S.R.; Thompson, F.R.; Dijak, W.D.; Larson, M.A.; Millspaugh, J.J. Simulated effects of forest management alternatives on landscape structure and habitat suitability in the Midwestern United States. For. Ecol. Manag. 2006, 229, 361-377. [CrossRef]

38. Wang, W.J.; He, H.S.; Thompson, F.R., III; Fraser, J.S.; Hanberry, B.B.; Dijak, W.D. The importance of succession, harvest, and climate change in determining future forest composition changes of the U.S. Central Hardwood Forests. Ecosphere 2015, 6, art277. [CrossRef]

39. Fraser, J.S.; He, H.S.; Shifley, S.R.; Wang, W.J.; Thompson, F.R. Simulating stand-level harvest prescriptions across landscapes: LANDIS PRO harvest module design. Can. J. For. Res. 2013, 43, 972-978. [CrossRef]

40. McNab, W.H.; Cleland, D.T.; Freeouf, J.A.; Keys, J.E., Jr.; Nowacki, G.J.; Carpenter, C.A. Description of Ecological Subregions: Sections of the Conterminous United States; U.S. Department of Agriculture, Forest Service: Washington, DC, USA, 2007.

41. Burns, R.M.; Honkala, B.H. Silvics of North America: Volume 2: Hardwoods. In Agriculture Handbook 654; U.S. Department of Agriculture, Forest Service: Washington, DC, USA, 1990.

42. Wang, W.J.; He, H.S.; Thompson, F.R., III; Fraser, J.S.; Dijak, W.D. Changes in forest biomass and tree species distribution under climate change in the northeastern United States. Landsc. Ecol. 2016, 32, 1399-1413. [CrossRef]

43. Loehle, C. Tree life history strategies: The role of defenses. Can. J. For. Res. 1988, 18, 209-222. [CrossRef]

44. Woodall, C.; Conkling, B.; Amacher, M.; Coulston, J.; Jovan, S.; Perry, C.; Schulz, B.; Smith, G.; Will Wolf, S. The Forest Inventory and Analysis Database Version 4.0: Database Description and Users Manual for Phase 3; Gen. Tech. Rep. NRS-61; U.S. Department of Agriculture, Forest Service, North Central Forest Experiment Station: Newtown Square, PA, USA, 2010.

45. Dijak, W. Landscape Builder: Software for the creation of initial landscapes for LANDIS from FIA data. Comput. Ecol. Softw. 2013, 3, 17-25. [CrossRef]

46. Regelbrugge, J.C.; Smith, D.W. Postfire tree mortality in relation to wildfire severity in mixed oak forests in the Blue Ridge of Virginia. North. J. Appl. For. 1994, 11, 90-97.

47. Hély, C.; Flannigan, M.; Bergeron, Y. Modeling tree mortality following wildfire in the southeastern Canadian mixed-wood boreal forest. For. Sci. 2003, 49, 566-576.

48. Woolley, T.; Shaw, D.C.; Ganio, L.M.; Fitzgerald, S. A review of logistic regression models used to predict post-fire tree mortality of western North American conifers. Int. J. Wildl. Fire 2012, 21, 1. [CrossRef]

49. Loomis, R.M. Estimating Fire-Caused Mortality and Injury in Oak-Hickory Forests; U.S. Dept. of Agriculture, Forest Service, North Central Forest Experiment Station: St. Paul, MN, USA, 1973.

50. Dey, D.C.; Johnson, P.S.; Garrett, H.E. Modeling the regeneration of oak stands in the Missouri Ozark Highlands. Can. J. For. Res. 1996, 26, 573-583. [CrossRef] 
51. Brose, P.H.; Dey, D.C.; Phillips, R.J.; Waldrop, T.A. A meta-analysis of the fire-oak hypothesis: Does prescribed burning promote oak reproduction in Eastern North America? For. Sci. 2013, 59, 322-334. [CrossRef]

52. Kinkead, C.S.; Stambaugh, M.C.; Kabrick, J.M. Mortality, scarring, and growth in an oak woodland following prescribed fire and commercial thinning in the Ozark Highlands. For. Ecol. Manag. 2017, 403, 12-26. [CrossRef]

53. Eidenshink, J.; Schwind, B.; Brewer, K.; Zhu, Z.; Quayle, B.; Howard, S. A project for monitoring trends in burn severity. Fire Ecol. 2007, 3, 3-21. [CrossRef]

54. Elliott, K.J.; Hendrick, R.L.; Major, A.E.; Vose, J.M.; Swank, W.T. Vegetation dynamics after a prescribed fire in the southern Appalachians. For. Ecol. Manag. 1999, 114, 199-213. [CrossRef]

55. Dey, D.C.; Hartman, G. Returning fire to Ozark Highland forest ecosystems: Effects on advance regeneration. For. Ecol. Manag. 2005, 217, 37-53. [CrossRef]

56. Hodgkins, E.J. Effects of fire on undergrowth vegetation in upland southern pine forests. Ecology 1958, 39, 36. [CrossRef]

57. Waldrop, T.A.; Lloyd, F.T. Precommercial thinning a sapling-sized loblolly pine stand with fire. South. J. Appl. For. 1988, 12, 203-207. [CrossRef]

58. McNab, W.H. An overcrowded loblolly pine stand thinned with fire. South. J. Appl. For. 1977, 1, $24-26$. [CrossRef]

59. Whittier, T.R.; Gray, A.N. Tree mortality based fire severity classification for forest inventories: A Pacific Northwest national forests example. For. Ecol. Manag. 2016, 359, 199-209. [CrossRef]

60. Shaw, J.D.; Goeking, S.A.; Menlove, J.; Werstak, C.E. Assessment of fire effects based on Forest Inventory and Analysis data and a long-term fire mapping data set. J. For. 2017, 115, 258-269. [CrossRef]

61. Lucash, M.S.; Scheller, R.M.; Kretchun, A.M.; Clark, K.L.; Hom, J. Impacts of fire and climate change on long-term nitrogen availability and forest productivity in the New Jersey Pine Barrens. Can. J. For. Res. 2014, 44, 404-412. [CrossRef]

62. Luo, X.; He, H.; Liang, Y.; Wang, W.; Wu, Z.; Fraser, J. Spatial simulation of the effect of fire and harvest on aboveground tree biomass in boreal forests of Northeast China. Landsc. Ecol. 2014, 29, 1187-1200. [CrossRef]

63. Lenihan, J.M.; Bachelet, D.; Neilson, R.P.; Drapek, R. Simulated response of conterminous United States ecosystems to climate change at different levels of fire suppression, $\mathrm{CO}_{2}$ emission rate, and growth response to $\mathrm{CO}_{2}$. Glob. Planet. Chang. 2008, 64, 16-25. [CrossRef]

64. Yospin, G.I.; Bridgham, S.D.; Neilson, R.P.; Bolte, J.P.; Bachelet, D.M.; Gould, P.J.; Harrington, C.A.; Kertis, J.A.; Evers, C.; Johnson, B.R. A new model to simulate climate-change impacts on forest succession for local land management. Ecol. Appl. 2015, 25, 226-242. [CrossRef]

65. Liu, S.; Bond-Lamberty, B.; Hicke, J.A.; Vargas, R.; Zhao, S.; Chen, J.; Edburg, S.L.; Hu, Y.; Liu, J.; McGuire, A.D.; et al. Simulating the impacts of disturbances on forest carbon cycling in North America: Processes, data, models, and challenges. J. Geophys. Res. Biogeosci. 2011, 116, 1-22. [CrossRef] 